\title{
Temporal variations and change in forest fire danger in Europe for 1960-2012
}

\author{
A. Venäläinen ${ }^{1}$, N. Korhonen ${ }^{1}$, O. Hyvärinen ${ }^{1}$, N. Koutsias ${ }^{2}$, F. Xystrakis ${ }^{2}$, I. R. Urbieta ${ }^{3}$, and J. M. Moreno ${ }^{3}$ \\ ${ }^{1}$ Finnish Meteorological Institute, Climate Change Research Unit, P.O. Box 503, 00101 Helsinki, Finland \\ ${ }^{2}$ Department of Environmental and Natural Resources Management, University of Ioannina, G. Seferi 2, \\ 30100 Agrinio, Greece \\ ${ }^{3}$ Department of Environmental Sciences, University of Castilla-La Mancha, 45071 Toledo, Spain
}

Correspondence to: A. Venäläinen (ari.venalainen@fmi.fi)

Received: 10 September 2013 - Published in Nat. Hazards Earth Syst. Sci. Discuss.: 6 November 2013

Revised: 7 April 2014 - Accepted: 23 April 2014 - Published: 11 June 2014

\begin{abstract}
Understanding how fire weather danger indices changed in the past and how such changes affected forest fire activity is important in a changing climate. We used the Canadian Fire Weather Index (FWI), calculated from two reanalysis data sets, ERA-40 and ERA Interim, to examine the temporal variation of forest fire danger in Europe in 1960-2012. Additionally, we used national forest fire statistics from Greece, Spain and Finland to examine the relationship between fire danger and fires. There is no obvious trend in fire danger for the time period covered by ERA-40 (1960-1999), whereas for the period 1980-2012 covered by ERA Interim, the mean FWI shows an increasing trend for southern and eastern Europe which is significant at the $99 \%$ confidence level. The cross correlations calculated at the national level in Greece, Spain and Finland between total area burned and mean FWI of the current season is of the order of 0.6 , demonstrating the extent to which the current fire-season weather can explain forest fires. To summarize, fire risk is multifaceted, and while climate is a major determinant, other factors can contribute to it, either positively or negatively.
\end{abstract}

\section{Introduction}

During the last century, global average surface temperatures in the world have increased by about $0.78^{\circ} \mathrm{C}$ (IPCC, 2013). However, this change in surface temperature has not been uniform across global regions. In Europe the decadal mean surface temperature has risen by about $1.3{ }^{\circ} \mathrm{C}$ from pre-industrial times until 2002-2011 (Haylock et al., 2008;
EEA, 2012). During the last 50 years, warming has been most pronounced in the Iberian Peninsula, central and northeastern Europe, and in mountainous regions; for the Iberian Peninsula, this warming has been most evident in summer (Haylock et al., 2008; EEA, 2012). In addition, warm extremes have become more frequent and cold extremes more rare. As an example, Della-Marta et al. (2007) showed that, in western Europe, the average length of summer heat waves is now twice as long as in 1880, and is accompanied by a tripling in the occurrence of hot days. Precipitation changes are not uniform across Europe; while increases in this have been observed in the north (Scandinavia and the Baltic states) a decrease is apparent in some southern areas, like in the Iberian Peninsula and especially in north-western Spain and northern Portugal (EEA, 2012). Warming trends in the form of increasing daily air temperature extremes dominated central and western Europe, while in the same region there are indications of an insignificant increase in dry spells (Moberg and Jones, 2005). Additionally, Lloyd-Hughes and Saunders (2002) have drawn attention to drying tendencies over central Europe which are stronger for the winter period.

These observed changes in climate have the potential to affect fire danger and, ultimately, forest fire activity. In this context, it is interesting to determine whether fire-weather danger has changed in Europe during the last decades. Fire danger indices are commonly used to assess fire potential, and warnings are regularly issued by fire agencies based on them. Fire danger indices combine several relevant climatic/weather variables into suitable format that, for example, forest fires services use to organize their response to 
forecasted risks (Andrews et al., 2003; Fujioka et al., 2008; Camia et al., 2010). Fire danger indices allow for comparisons between fire-season severity across years and regions. The Canadian Fire Weather Index, FWI, based on the Canadian Forest Fire Danger Rating System (Van Wagner, 1987), is one of the most widely used indices, in use in countries across North and South America, Europe and Asia (De Groot et al., 2006).

Temporal and spatial variation of fire danger has been studied, for example, by Camia et al. (2008) in Europe using the ERA Interim data set (Dee at al., 2011) and the Seasonal Severity Rating index based on FWI. According to their analyses, from 1981 to 2010 and onwards, there have been statistically highly significant increases in fire danger in southeastern Europe and the southern-most regions of the Iberian Peninsula. Mäkelä et al. (2012) used the fire danger index operational in Finland to estimate the long-term 1908-2011 temporal variation of fire danger in Finland. They found out that the year-to-year variation in fire danger was large, but no significant trend could be detected. Wastl et al. (2012) examined the long-term trends in meteorological forest fire danger in the Alps during the period 1951-2010 using several fire danger rating indices, and found significant increases in the western and southern Alps. The increase was quite small in the northern Alps, and no clear signal could be observed in the inner Alpine valleys. Bedia et al. (2012) tested different model reanalysis data sets in the calculation of fire danger for the Iberian Peninsula and found that, for most parts of Spain, the summer season fire danger has increased. They also noted that the results based on the ERA Interim data set (Dee et al., 2011) were more robust than the results based on the NCEP data set (Kistler et al., 2001).

The relationships between fire danger indices and forest fires in Europe have been explored in a number of studies. Koutsias et al. (2013) examined trends in air temperature and their relationship to forest fires in Greece during the years 1894-2010 and found that both increased through time, particularly during the last 40 years. The annual number of fires and area burnt was strongly correlated with the maximum temperatures and summer heat waves. An evaluation of FWI performed recently using fire observations of a 15 -year period for Greece confirmed that the index is capable of predicting fire occurrence (Karali et al., 2014). Additionally, Dimitrakapoulos et al. (2011a) found that there was a positive correlation between the annual drought and fire occurrence in Greece during the years 1961-1997. Similar analysis relating downscaling methods and future projections of the various FWI in the Iberian Peninsula and Greece was performed by Bedia et al. (2013). Positive correlations between FWI values and fires have been found in other parts of the world, such as in Canada (Gillet et al., 2004).

High fire danger caused by dry, hot and windy weather increases the occurrence of fires. However, most ignitions of fires are caused by human activities. For example, according to Ganteume et al. (2013) only about $7 \%$ of the fires (whose cause was known) in northern Europe, $0.5 \%$ in central Europe and $5 \%$ in southern Europe were caused by natural sources. Similarly, a review by Bowman et al. (2009) showed that the variation in the occurrence of fires cannot be predicted by climate forcing alone, but that other aspects such as human behaviour and the effectiveness of fire detection and suppression systems must also be taken into account. To summarize, weather conditions make the occurrence of fires possible and humans in most cases ignite the fire.

Though weather and climate are not the sole forcing mechanisms of forest fires, they determine the conditions for fires to occur and spread, once an ignition occurs, and this way remain as the key factors for explaining the spatial and temporal variability of fires at all scales, including the whole globe. Therefore, in this study the main objective is to investigate whether the recent changes in climate have had a discernible impact on weather-related fire danger in Europe during the past five decades. To answer this question we have examined the temporal variation of the danger as expressed by FWI due to the variation in meteorological conditions over different European regions during 1960-2012 using ERA-40 (Uppala et al., 2005) and ERA Interim (Dee et al., 2011) data sets. Additionally, we also have demonstrated the significance of fire-weather indices in forest fires in three test sites (Greece, Spain and Finland) by calculating the cross correlation between fire statistics and mean FWI values.

\section{Material and methods}

\subsection{European level}

Europe was divided into four regions (Fig. 1) and only the grid boxes containing land were studied. The area denoted as southern Europe includes part of northern Africa for this study. The southern region represents Mediterranean warm climate, the eastern region continental Eurasian climate, the western area more humid Atlantic climate, and the northern region cool Fennoscandian climate. In addition to regional mean values, the FWI trend was analysed for each grid square.

We used ERA-40 (Uppala et al., 2005) for the years 1960-1999 and ERA Interim (Dee et al., 2011) data sets for the years 1980-2012 to calculate the Canadian FWI for each year. ERA-40 and ERA Interim are atmospheric reanalysed data sets that are created by the European Centre for Medium-Range Weather Forecasts' (ECMWF) modelling system. These data sets are based on all available and appropriate observational data, such as weather stations, radio soundings, ship measurements, satellite measurements etc. The spatial resolution used in this study was $2.5^{\circ} \times 2.5^{\circ}$ and $1.5^{\circ} \times 1.5^{\circ}$ for ERA-40 and for ERA Interim respectively. The calculation of FWI was done for the whole year but the main parameters of interest were the March-September mean value of FWI, and the number of days when FWI was 

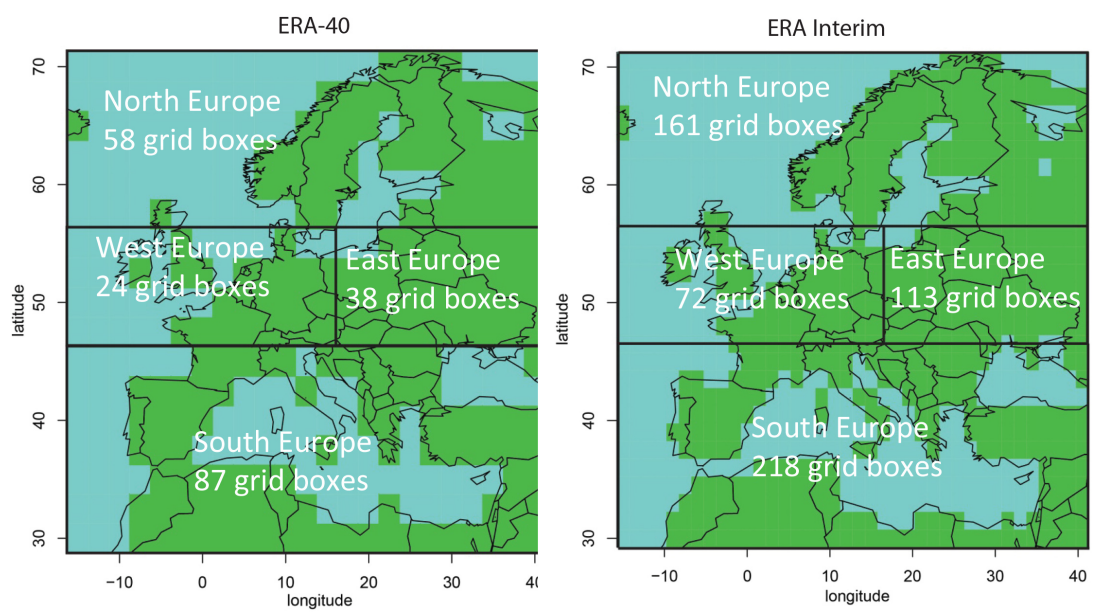

Figure 1. The four European regions analysed for ERA-40 (left panel) and ERA Interim (right panel) data sets.

larger than 20 or larger than 45 in March-September. The March-September period constitutes the main fire season in Europe. In northern Europe the season usually starts in May at the earliest after snow has melted, whereas in Southern Europe the season is centred in the summer months, although in some areas out-of-summer fires are also common. Moriondo et al. (2006) used an FWI threshold value of 45 for the Mediterranean region in their study on the impact of climate change on fire danger. Lehtonen et al. (2014) selected limits based on the study of Tanskanen et al. (2005) and the limits were FWI > 32 (extreme risk), 17-32 (high risk), 1631 (medium risk) and $<8$ low risk. The threshold of 20 used in this study can be regarded as applicable for the cool climate regions. In southern Europe, FWI values larger than 45 are relatively common, whereas in the rest of Europe they occur only very occasionally. This is why the analyses using the threshold of 45 were done only for the southernmost area and for the rest of the areas analyses were done using a threshold of 20. The results for the exceedance of threshold were presented as probabilities in percent $(\%)$ :

Probability $=$

$100 \times[$ no. of cases $/($ no. grid boxes $\times$ no. of days) $]$.

FWI has six components describing the moisture content of the surface layers, and the systems also predict various aspects of the fire behaviour. The input parameters required for deriving FWI are the midday temperature, relative humidity and wind speed, together with the precipitation sum of the previous $24 \mathrm{~h}$. FWI is a dimensionless quantity indicating the fire danger. The FWI system was originally developed empirically for Canadian boreal conditions; however, the FWI indices have been proved to be good indicators of fire conditions in many other parts of the world, and have been proposed as the basis for a global early warning system for fires (De Groot et al., 2006).
In this study, the 12:00 UTC values were used. As the region used in the study is roughly from $5^{\circ} \mathrm{W}$ to $40^{\circ} \mathrm{E}$, the 12:00 UTC value means four different solar times, which creates some inaccuracy in the calculations. However, as we are now interested in long-term temporal changes in FWI the exact numerical values are not that critical from that point as long as the method remains the same throughout the whole calculation period.

The calculation of FWI and trend of FWI was performed with the R package "fume" created by the Santander Meteorology Group (http://www.meteo.unican.es), which was used by Bedia et al. (2012). The trend was analysed using the Mann-Kendall test (Mann, 1945; Kendall, 1975) and the gradient of the trend line was calculated using Sen's slope estimate (Sen, 1968). The classical Mann-Kendall trend test evaluates the null hypothesis, $H_{0}$, that a time series is random (independent and identically distributed) against the alternative hypothesis, $H_{1}$, that the series exhibits a monotonic trend. However, the temporal autocorrelation can cause the classical test to reject the null hypothesis even if it is true. In its modified version, a correction factor is applied to the original variance formulation, accounting for the effective sample size in the presence of temporal autocorrelation (Bedia et al., 2012). This test is shown to be robust in the presence of serially correlated time series data (Hamed and Rao, 1998). Sen's slope estimate is the median of slopes calculated from all possible data value pairs. This estimate is more robust against outliers than, for example, least-squares regression. Trends were calculated separately for ERA-40 and ERA Interim data sets. In addition, to allow analyses covering the period 1960-2012, we estimated the ERA-40/ERA Interim coefficient from their common period (1980-1999) and extended the respective FWI time series on the basis of the estimated coefficient for the missing years. This resulted in two FWI time series, one corresponding to ERA-40 and one to ERA Interim for the period 1960-2012. 


\subsection{National level}

Fire statistics at the national scalewere available for Greece for the period 1977-2010, for Spain for the period 19691999 and for Finland for the period 1960-2012. The Greek data comprise a subset from a national wildfire time series data (Koutsias et al., 2013) originally obtained from the National Statistical Service of Greece (NSSG), the Hellenic Forest Service (HFS), the Hellenic Fire Brigade (HFB) and Kailidis and Karanikola (2004). The Spanish data covered the 1961-2010 period and were obtained from the national forest fire statistics (EGIF, General Statistics of Wildfires) of the Spanish Ministry of Agriculture and Environment. The Finnish fire statistics have been published by the Finnish Forest Research Institute (2010).

For the national level calculations, in Spain, Greece and Finland we selected the FWI values to be analysed for the mid-summer months from June to September both from ERA-40 and ERA Interim data sets using only the grid cells located within peninsular Spain, Greece and Finland respectively. To identify possible abrupt shifts in the mean values of FWI in the time series, indicating distinct time periods, we applied the F statistic and the generalized fluctuation tests as described in Zeileis et al. (2003) and implemented in the R package "strucchange" (Zeileis et al., 2002). We applied both tests with a 0.1 bandwidth resulting in 5-year data window. To identify the optimal number of breakpoints, we adopted the method described in Zeileis et al. (2003). Within the defined segments, based on the breakpoints, we analysed the trend using the Mann-Kendall test, and the slope of the trend line was calculated using Sen's slope estimate.

Total burned area and number of fires were ln-transformed and the cross correlations with FWI were estimated applying the modified Pearson's correlation coefficient accounting for the autocorrelation of the time series using the approach followed by Meyn et al. (2010) by calculating the effective sample size that arises when a first-order correlation coefficient is considered. Additionally, cross correlations between FWI and the untransformed fire statistics were estimated by means of the non-parametric Spearman's coefficient also accounting for the autocorrelation in the time series. The crosscorrelation analysis was performed using \pm 3 lags (years) within the defined time segments in order to explore any bivariate lagged relationships between area burned and FWI.

\section{Results}

\subsection{European level}

\subsubsection{Response of mean FWI}

The temporal variation of mean FWI values since 1960 displays a relatively large year-to-year variation (Fig. 2). For the years 1980-1999 there is an overlap between ERA-40 and ERA Interim data sets, with an overall good agreement in
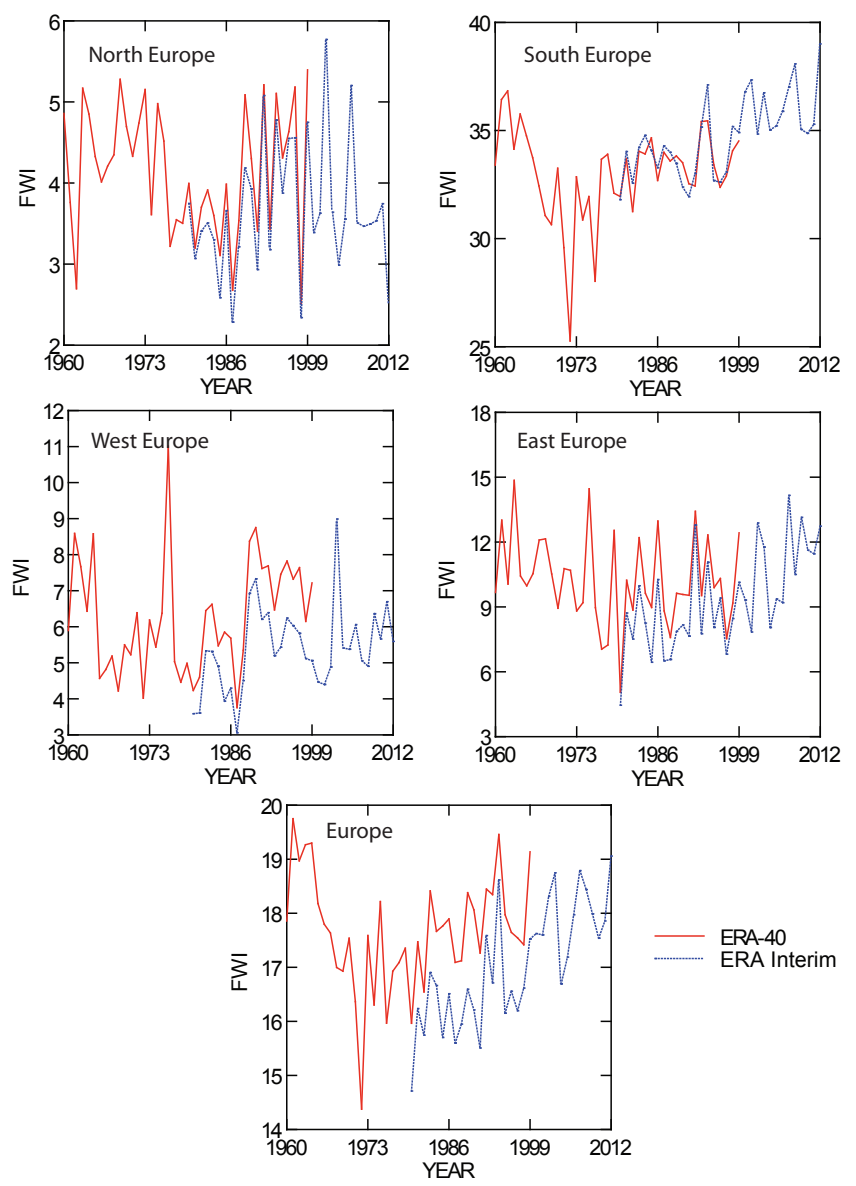

Figure 2. The year-to-year variation of March-September mean FWI from ERA-40 and ERA Interim data sets for four selected areas (see Fig. 1) and for the whole of Europe.

the values of FWI from both. In southern Europe, the values based on ERA Interim are about the same as from ERA-40, whereas elsewhere FWI calculated from ERA-40 is systematically higher (Fig. 2).

According to the trend analyses for ERA Interim-based FWI (Table 1), there was a significant upward trend at the $99 \%$ level for southern and eastern Europe. The ERA Interim-based FWI trend for all of Europe also showed the same very high $99 \%$ confidence level. However, ERA-40based FWI did not exhibit any trend. The results show that during recent years, from approximately 1995 onwards, a tendency toward a higher FWI can be detected in the time series of Era Interim in all sub regions tested but the north. When we look at the trend for the whole period of 19602012 in the time series created by completing the ERA Interim backwards using ERA-40 data and the relationship defined using the common period of 1980-1999, the statistically significant rising trend at the $99 \%$ level was found for the southern Europe. For eastern and western Europe the rising trend was statistically significant at $90 \%$ level, and for 
Table 1. Trend and gradient of the mean March-September FWI values as calculated for the regions of Europe in Fig. 1 using the modified Mann-Kendall test and Sen's method on ERA-40 and ERA Interim data sets. The following symbols indicate significance at level $\alpha=$ $0.01(* * *), \alpha=0.05(* *)$ and $\alpha=0.1(*)$.

\begin{tabular}{lrrrrrr}
\hline Time series & First year & Last year & No. of years & Test Z & Signific. & Gradient \\
\hline ERA-40 Europe & 1960 & 1999 & 40 & 0.22 & & 0.005 \\
ERA-40 north & 1960 & 1999 & 40 & -0.69 & & -0.006 \\
ERA-40 south & 1960 & 1999 & 40 & 0.30 & & 0.011 \\
ERA-40 east & 1960 & 1999 & 40 & -1.13 & & -0.024 \\
ERA-40 west & 1960 & 1999 & 40 & 1.34 & & 0.040 \\
ERA Inter. Europe & 1980 & 2012 & 33 & 4.54 & $* * *$ & 0.087 \\
ERA Inter. north & 1980 & 2012 & 33 & 0.60 & & 0.009 \\
ERA Inter. south & 1980 & 2012 & 33 & 5.58 & $* * *$ & 0.116 \\
ERA Inter. east & 1980 & 2012 & 33 & 3.64 & $* * *$ & 0.155 \\
ERA Inter. west & 1980 & 2012 & 33 & 1.65 & $*$ & 0.041 \\
\hline
\end{tabular}

northern Europe there was no trend. The spatial analysis of the trends (Fig. 3) showed that there was a very clear statistically significant rising trend in ERA Interim-based FWI in eastern Europe and also in the eastern Iberian Peninsula and much of France. A similar analysis for ERA-40-based FWI showed that there were statistically significant trends in a few cells only, with exception of the central Europe, in which there was a slight rising trend.

\subsubsection{Response of FWI exceeding selected thresholds}

The time series for the number of days when FWI exceeds 20 or 45 (Figs. 4 and 5) showed the same features as the time series for mean FWI based on Era Interim data (Fig. 2), with the number of days exceeding the selected threshold value becoming more frequent during the last 10 years or so. No trend was shown by ERA-40-based FWI, which was only available until 1999 .

According to the trend analyses for the number of days where FWI > 20 (Table 2), ERA Interim-based FWI displays an upward trend significant at the $99 \%$ level for southern Europe and at the $95 \%$ level for eastern Europe. The trend shown for the whole of Europe also reaches the $99 \%$ confidence level. For the number of days where FWI $>45$ the trend is significant at the $99 \%$ level for southern Europe. Again, there is no trend indicated by ERA-40-based FWI.

\subsection{National level}

\subsubsection{Greece}

The analysis of whether the mean FWI based on ERA-40 and ERA Interim data for Greece changes over time, based on the $\mathrm{F}$ statistic and the generalized fluctuation tests, did not result in any statistically significant breakpoint. However, there is a distinct period of low FWI values (Fig. 6). In order to objectively assess the time window of the period with distinctly low values of FWI, the breakpoint analysis (forcing for two breaks) resulted in the years 1970 and 1976. Trend analysis using the Mann-Kendall test and Sen's method did not reveal any significant positive or negative trend.

The cross-correlation analysis between the ERA-40 and ERA Interim-based FWI and the untransformed and transformed (ln) total area burned at the national scale in Greece within the period of 1977-2010 resulted in significant lag 0 coefficients (Fig. 7). Their values, as shown in Fig. 7, are 0.70 and 0.67 for ERA Interim and 0.69 and 064 for ERA-40 for the untransformed and the $1 n$-transformed values respectively. The correlation coefficients for the number of fires are considerably smaller than those of total burned area (see the Supplement).

\subsubsection{Spain}

The analysis of whether the mean FWI based on ERA-40 and ERA Interim data for Spain changes over time resulted in three breakpoints, in the years 1968, 1977 and 1999, therefore defining four distinct periods - i.e. 1960-1968, 1969-1977, 1978-1999 and 2000-2011 - for both data sets (Fig. 8). Here, it should be pointed out that the 1977 breakpoint could be an outcome of the combination between the extremely low FWI values observed during 1971 and 1972 (Fig. 8) and the short bandwidth that was selected for the analysis ( 5 years). Within the three distinct periods, none of the data series was found to have a significant trend using the Mann-Kendall test and Sen's method. However, in the period defined when the last three sub-periods were merged (1969-2011), FWI of both data sets, ERA-40 and ERA Interim, as modified for completing the missing years, showed significant positive trends at significance level of 0.001 similar to the positive trends observed of FWI time series data of ERA-40 and ERA Interim south. In the case of the ERA40-based FWI, a positive trend is observed when the original values that cover the period 1969-2001 $(p=0.001)$, while in the case of ERA Interim-based FWI, a positive trend is observed when the original values are used covering the period $1980-2012(p=0.01)$. 
(a)

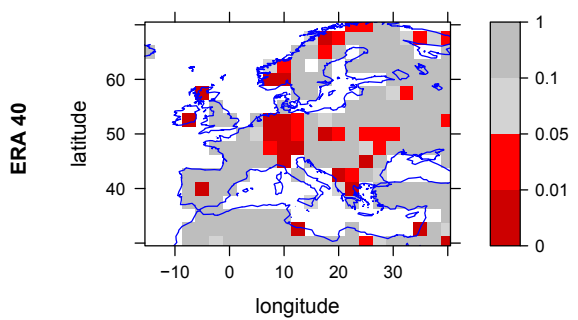

(c)

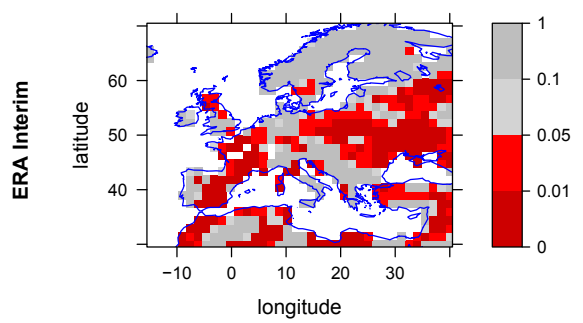

(b) Sen's slope

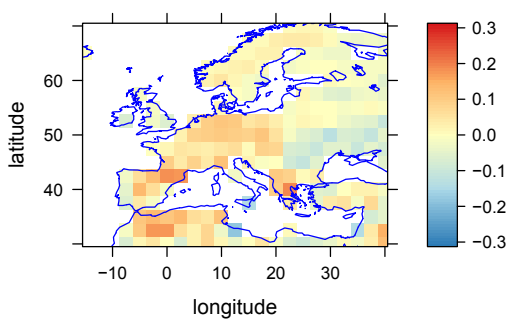

(d) Sen's slope

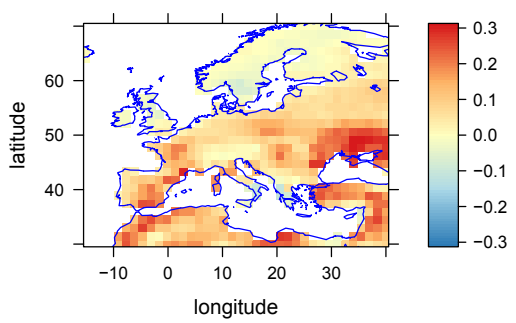

Figure 3. Trend of March-September mean FWI calculated using the ERA-40 data set for 1960-1999 (b) and the ERA Interim data set for 1980-2012 (d). The statistical significance $(\alpha)$ is shown at levels 0.01, 0.05 and 0.1 for ERA-40 (a) and ERA Interim (c).
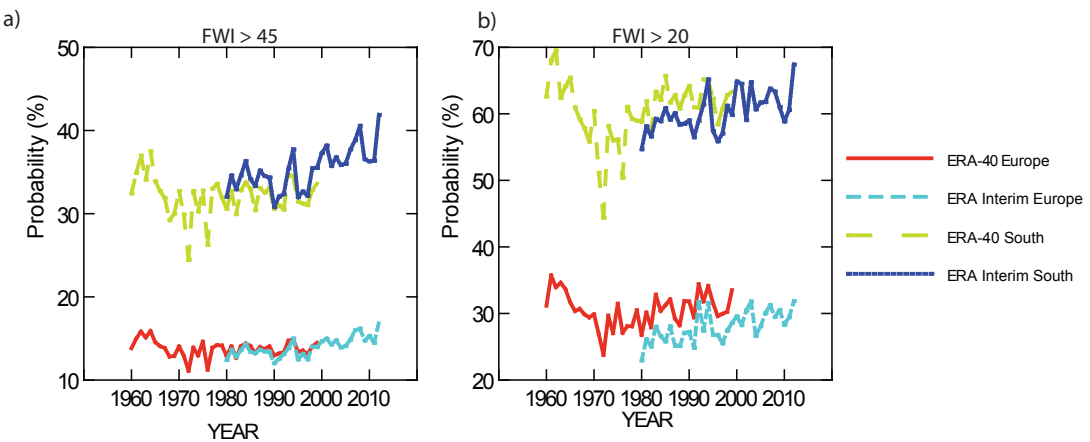

Figure 4. The year-to-year variation of March-September FWI values above 20 and above 45 from ERA-40 and ERA Interim data sets calculated for southern Europe and for the whole of Europe. The value is expressed as a probability (Eq. 1).

For the cross-correlation analysis we defined the period from 1969 to 1999 (i.e. not considering the breakpoint of 1978). The cross-correlation graphs between FWI of ERA40 and ERA Interim south and the untransformed and transformed (ln) total area burned at the national scale in Spain (Fig. 9) indicate significant correlations at lag 0. The correlation coefficients, as shown in Fig. 9, are 0.50 and 0.62 for ERA Interim and 0.59 and 0.67 for ERA- 40 for the untransformed and the ln-transformed burned area values respectively. The correlation coefficients for the number of fires are smaller than those of total burned area, though not as much as in the case of Greece (see the Supplement).

\subsubsection{Finland}

No trend in FWI was found for Finland, only large year-toyear variation (Fig. 10). The correlation between the burned area and FWI was roughly as high as in the case of the two Mediterranean countries studied above, i.e. around 0.6 (Fig. 11). Specifically, the correlation coefficients, as shown in Fig. 11, are 0.63 and 0.59 for ERA Interim and 0.61 and 0.57 for ERA-40 for the untransformed and the lntransformed burned area values respectively. The correlation coefficients for the number of fires are smaller than those of total burned area, though not as much as in the case of Greece (see the Supplement). 
Table 2. Trend and gradient of the March-September FWI values higher than 20 or higher than 45 as calculated for the different areas of Europe (Fig. 1) using the modified Mann-Kendall test and Sen's method and ERA-40 and ERA Interim data sets. The following symbols indicate significance at level $\alpha=0.01(* * *), \alpha=0.05(* *)$ and $\alpha=0.1$.

\begin{tabular}{lrrrrrr}
\hline Time series & First year & Last year & No. of years & Test Z & Signific. & Gradient \\
\hline ERA-40 Europe $>20$ & 1960 & 1999 & 40 & 0.72 & & 0.004 \\
ERA-40 south $>20$ & 1960 & 1999 & 40 & 0.60 & & 0.025 \\
ERA-40 north $>20$ & 1960 & 1999 & 40 & -1.11 & & -0.037 \\
ERA-40 west $>20$ & 1960 & 1999 & 40 & 1.16 & & 0.094 \\
ERA-40 east $>20$ & 1960 & 1999 & 40 & -1.22 & & -0.095 \\
ERA-40 Europe $>45$ & 1960 & 1999 & 40 & -0.90 & & -0.011 \\
ERA-40 south $>45$ & 1960 & 1999 & 40 & -0.16 & & -0.006 \\
ERA Inter. Europe $>20$ & 1980 & 2012 & 33 & 3.98 & $* * *$ & 0.161 \\
ERA Inter. south $>20$ & 1980 & 2012 & 33 & 3.08 & $* * *$ & 0.166 \\
ERA Inter. north $>20$ & 1980 & 2012 & 33 & 0.64 & & 0.045 \\
ERA Inter. west $>20$ & 1980 & 2012 & 33 & 1.53 & & 0.081 \\
ERA Inter. east $>20$ & 1980 & 2012 & 33 & 3.33 & $* *$ & 0.391 \\
ERA Inter. Europe $>45$ & 1980 & 2012 & 33 & 4.11 & $* * *$ & 0.078 \\
ERA Inter. south $>45$ & 1980 & 2012 & 33 & 4.01 & $* * *$ & 0.145 \\
\hline
\end{tabular}

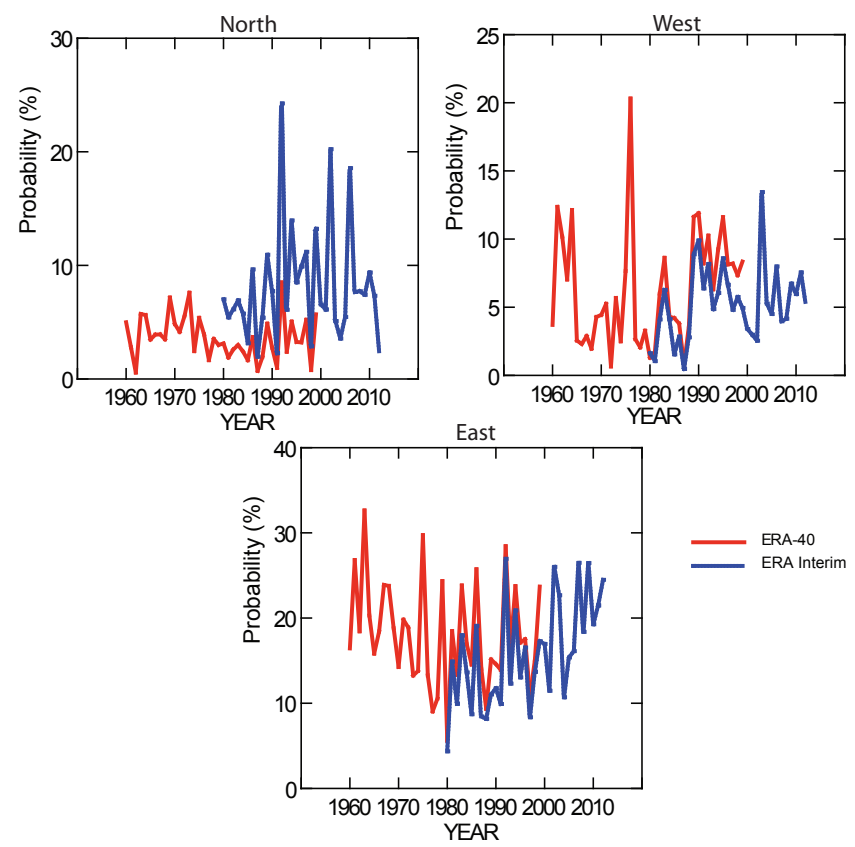

Figure 5. The year-to-year variation of March-September FWI values above 20 from ERA-40 and ERA Interim data sets calculated for north, west and east. Values are expressed as a probability (Eq. 1).

\section{Discussion}

The main purpose of this study was to detect the climate change signal in fire danger and to assess its importance for actual fire occurrence in two contrasting European regions, the Mediterranean and the boreal region, using various countries as examples. It is made apparent that the FWI trends observed in this study are compatible with the general trend towards climatic features characterized by warmer
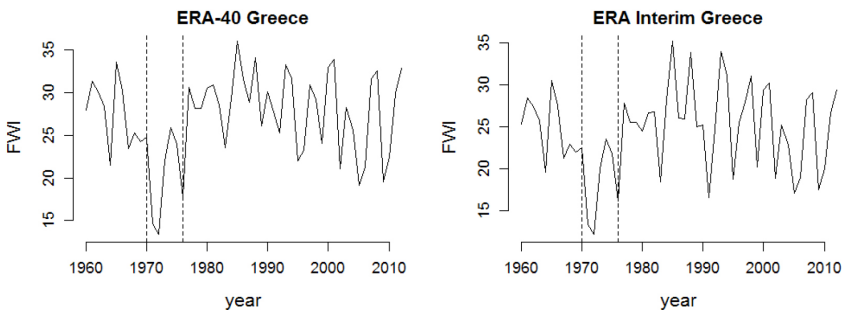

Figure 6. FWI time-series data based on ERA-40 and ERA Interim data for Greece. Vertical dotted lines correspond to forced breakpoints.

temperatures and changed precipitation patterns in Europe (Della-Marta et al., 2007; Haylock et al., 2008; EEA, 2012). The rise of fire danger during the last 40 years has occurred in southern and eastern Europe. In northern and western Europe temperature rise during summer season has not been that significant, and while precipitation has no decreasing trend, the net effect is that FWI did not exhibit a long-term trend either.

The temporal variations of FWI also depicts the longterm temporal variations of European climate; that is, early 1960s FWI had relatively high values in southern and southeastern Europe, followed by lower values in the late 1960s and early 1970s, and after that the change is characterized by a rising trend. An interesting detail is the area covering the northern side of the Black Sea, where FWI has a decreasing trend when calculated using ERA-40 and a notable increasing trend in ERA Interim. These variations demonstrate that although climate is warming, the long-term climate variations will remain, and also in the future, periods with lower FWI can be experienced even in areas characterized by an increasing trend of FWI. 

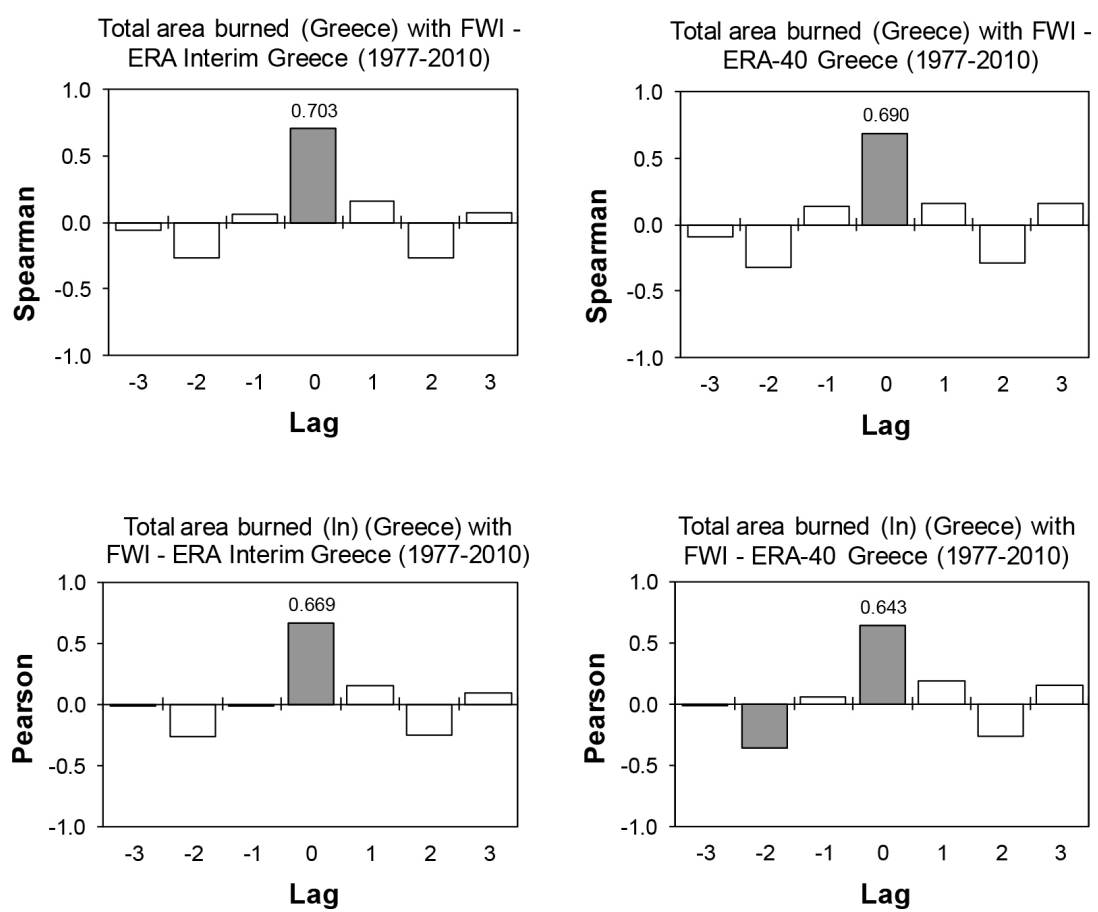

Figure 7. Cross-correlation graphs between total burned area (original and ln-transformed) at the national scale in Greece and FWI values estimated from ERA-40 and ERA Interim Greek data for the period 1977-2010 (grey columns indicate significant values at the 95\% confidence level).
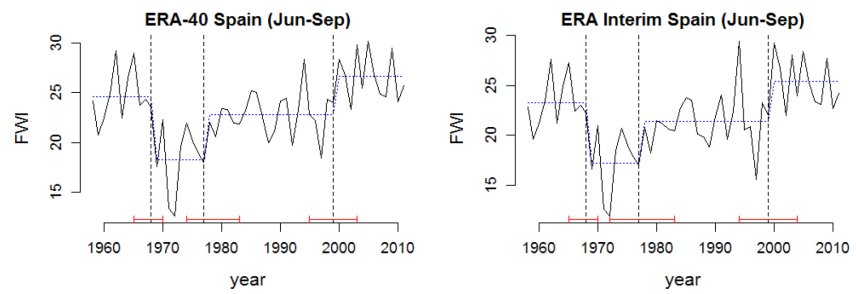

Figure 8. Breakpoints of FWI time-series data based on ERA-40 and ERA Interim for Spain. Vertical dotted lines correspond to breakpoints, while red horizontal lines correspond to the $95 \%$ confidence intervals of the estimated breakpoints. Blue lines represent the mean values of FWI for each identified segment.

More specifically, and focusing on the three countries studied, it has been shown that, generally and with significant variability among regions and seasons, rainfall amount in the Greek peninsula shows a trend of decline after the 1980s, which is confirmed from various sources (Maheras et al., 2000; Pnevmatikos and Katsoulis, 2006; Feidas et al., 2007). This further supports the argumentation of Dimitrakopoulos et al. (2011c) regarding an increase in summer drought episodes. In Spain, temperatures have increased, although not homogeneously, across the country (Brunet et al., 2007; Pérez and Boscolo, 2010; Fernández-Montes et al., 2013; Acero et al., 2014), while precipitation changes, although less robust, also evidence a tendency towards a reduction, particularly during the last half of the century in the lower south-eastern half of the country (Pérez and Boscolo, 2010; Beguería et al. 2011). Although the annual mean temperature has risen in Finland by around $1{ }^{\circ} \mathrm{C}$ since 1900, the summer season mean temperature has not risen during the past 50 years (Tietäväinen et al., 2010). Similarly, there is no trend in summer precipitation. This lack of trend in either temperature or precipitation is reflected in temporal variation of FWI calculated for Finland; that is, there is no trend, only large year-to-year variation typical for northern Europe's highly variable climate.

The identification of breakpoints in the various series analysed helped in defining homogenous periods in the FWI time series that could be used to test trend-free cross correlations with fire statistics, rather than making a thorough analysis of the observed FWI variability. It is interesting to observe that, although the analysis did not identify any significant breakpoint, the pattern between the FWI series from Greece and Spain is very similar and characterized by a distinct period of low FWI values during the 1970s. In Spain, this period begins earlier and the differences in FWI values between this period and the time period just before are higher. This is the main reason for the identification of significant breakpoints in the Spanish data but not in the Greek data. However, respective breaks in the mean air temperature time series over various regions in Greece in the early 1970s and middle 1990s (Nastos et al., 2011; Kolokythas and Argiriou, 2013) and in 

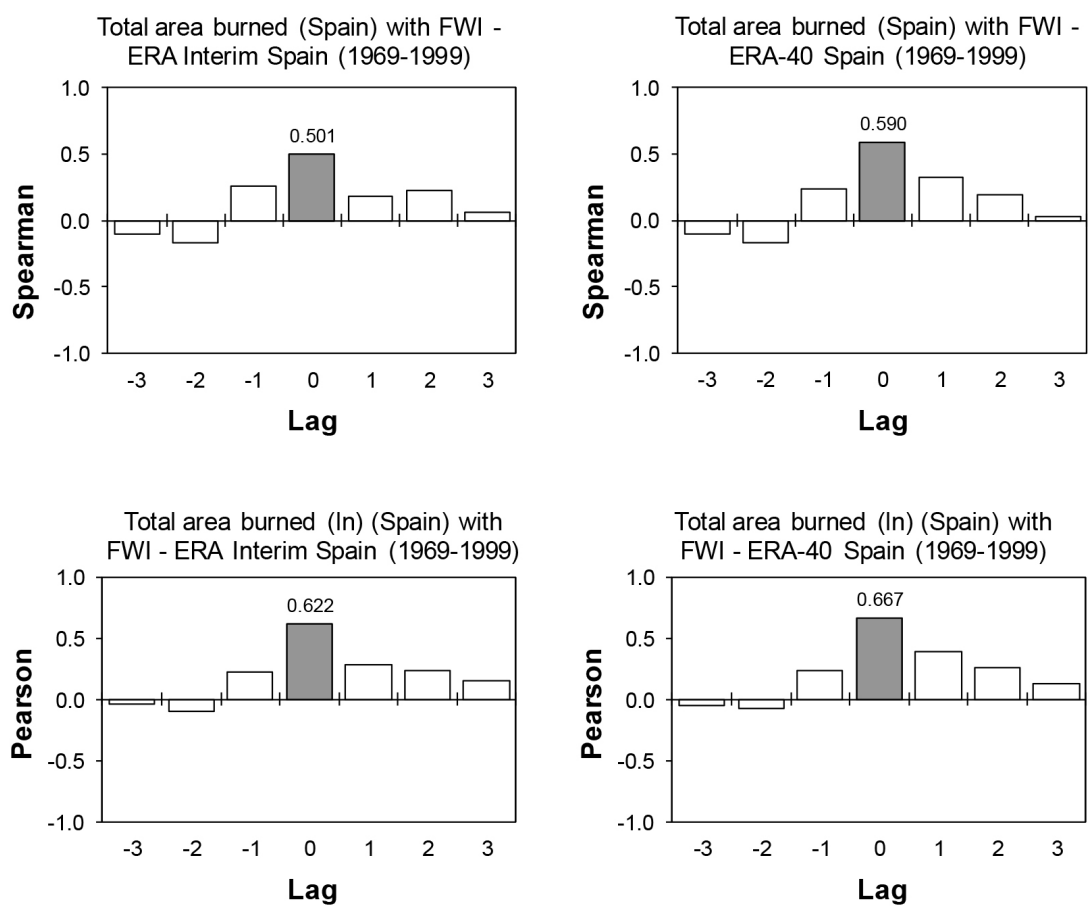

Figure 9. Cross-correlation graphs between total burned area (original and ln-transformed) at the national scale in Spain and FWI values estimated from ERA-40 and ERA Interim Spain data for the period 1969-1999 (grey columns indicate significant values at the $95 \%$ confidence level).
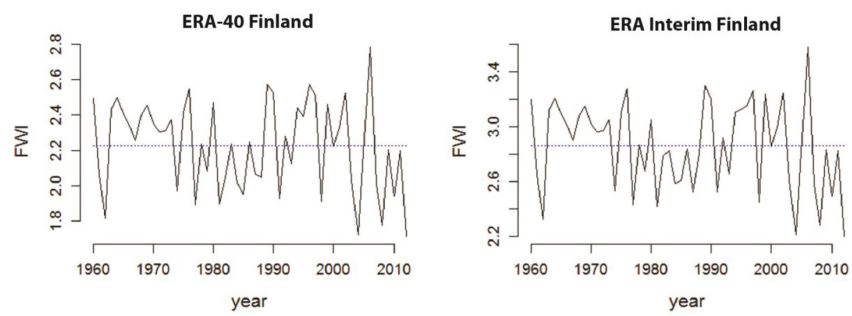

Figure 10. FWI time-series data based on ERA-40 and ERA Interim for Finland. Blue lines represent the mean values of FWI.

the precipitation time series between 1970 and 1980 (in the broader sense) (Pnevmatikos and Katsoulis, 2006; Feidas et al., 2007; Kalimeris et al., 2012) lead to the conclusion that an actual break in FWI series in the decade between 1970 and 1980 is also plausible. It should be noticed, however, that further testing is required in order to identify whether the breakpoints are artificial and due to exogenous variables or whether they actually indicate altering periods in the FWI values.

Correlations between fire statistics and FWI were apparent in all studied countries (Spain, Greece and Finland). As was shown here, the correlations between FWI and fire statistics were relatively high, and especially for Greece, they were similar to those estimated by Dimitrakopoulos et al. (2011b). This demonstrates, on the one hand, the causal effect of meteorological conditions on forest fires and, on the other hand, the importance of other factors such as vegetation/fuel, landscape and socioeconomics, including fire suppression, that are not related to climatic or meteorological conditions (Viedma et al., 2006, 2009; Carmo et al., 2011; Koutsias et al., 2013; Martínez-Fernández et al., 2013; Brotons et al., 2013). In all studied countries, Spain, Greece and Finland, the correlation coefficients of the number of fires are smaller than those of total burned area (see the Supplement). This can reflect in part the fact that fire statistics are more susceptible to being affected by small-size fires in particular. Area burned, however, is less subject to these spurious effects owing to the fact that large fires account for a high percentage of the total area burned, and statistics should be more robust in this regard (Moreno et al., 2011a; Pereira et al., 2011).

The profound and tight relation between weather and fire statistics has been demonstrated in numerous studies covering various parts and climate regions of the globe. Extreme fire weather is related to large fires in boreal ecosystems and sub-alpine forests (Beverly and Martell, 2005; Bessie and Johnson, 1995; Drobyshev et al., 2012). Similarly, in the Mediterranean region, the positive links between fire statistics and various weather components that indicate drought are apparent. Variables that most often correlate with burned area include simple weather parameters such as fire season precipitation (Vázquez and Moreno, 1993; Holden et al., 2007; Koutsias et al., 2013; Xystrakis and Koutsias, 

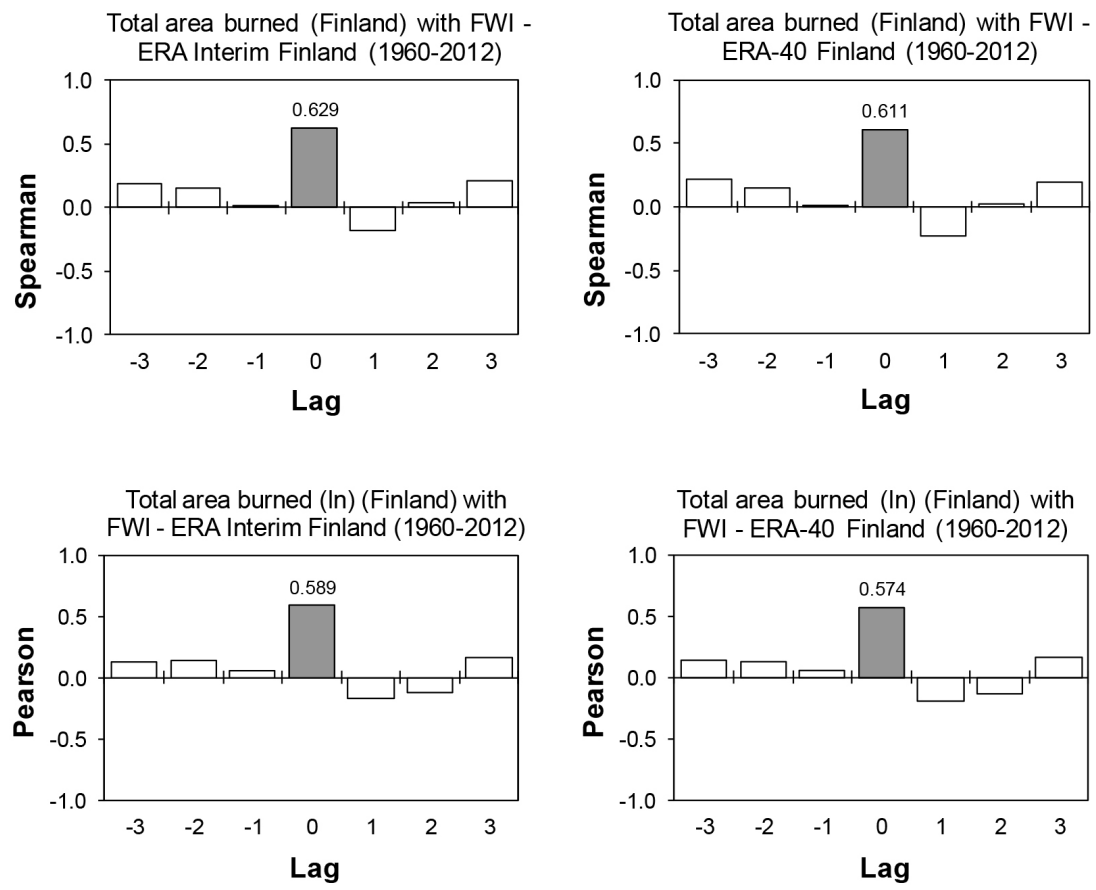

Figure 11. Cross-correlation graphs between total burned area (original and ln-transformed) at the national scale in Finland and FWI values estimated from ERA-40 and ERA Interim Finnish data for the period 1960-2012 (grey columns indicate significant values at the 95\% confidence level).

2013; Pausas, 2004), air temperature (Vázquez and Moreno, 1995; Piñol et al., 1998) or indices which, combining various weather parameters, quantify drought and fire danger (Carvalho et al., 2008; Camia and Amatulli, 2009). Although correlation does not necessarily imply causation, the links are strong and consistent, and the outputs of the present study also support this argumentation through the observed significant correlations. Such correlations between weather conditions and fire activity (including fire ignition and spread) are based on the control of weather in processes related to fuel moisture content and to the effect of wind in fire spread (Camia and Amatulli, 2009; Sullivan, 2009).

Large fires may account for more than $70 \%$ of the total annual area burned (Ganteaume and Jappiot, 2013), and weather may be the dominant factor in determining fire spread (Moreira et al., 2011), with wind speed being identified as the main weather component of large forest fires in Greece (Dimitrakopoulos et al., 2011a) and California (Moritz et al., 2010); however, a large part of variation remains unexplained if other parameters are excluded. The lack of topographic, socioeconomic and landscape parameters may hamper correlations, and this could partially be the reason for the relatively low correlation coefficients between FWI values and fire statistics. Such additional factors were found to play a major role in southern France (Ganteaume and Jappiot, 2013), where area burned is related to high vegetation cover. In central Spain, landscape variability (discontinuity) was an important parameter for controlling fire size, even if the vast majority of the fire events took place under severe fire weather with FWI larger than 30 (Viedma et al., 2009). The influence of landscape in fire spread is also indirectly revealed through the analysis of selectivity patterns of fires belonging to different size classes (Moreira et al., 2011). Large fires in Sardinia tend to selectively burn shrub and grassland (Bajocco and Ricotta, 2008), and in central Spain large fires showed selectivity towards conifers and areas near settlements and roads (Moreno et al., 2011b). Socioeconomic variables like unemployment and touristic pressure could be directly linked to area burned (Koutsias et al., 2010; Ganteaume and Jappiot, 2013) or major social processes, as, for example, rural migration and urbanization followed by land abandonment could indirectly favour fuel conditions that could lead to large fire events as long as the fire is initiated (Koutsias et al., 2012). Similarly, humid-cool weather conditions could control fire initiation and spread even in the most fire prone ecosystems, indicating the dual role of weather in controlling fire size (Xystrakis et al., 2014). It can be argued that fire weather triggers or inhibits the landscape, topographic and socioeconomic variables in emerging as dominant factors of fire spread (Bradstock, 2010; Moreira et al., 2011). 


\section{Conclusions}

In this study we examined the temporal variation of climate and fire weather danger in Europe using FWI. The results show an increase in fire danger in southern and eastern Europe after around 1970, and no clear signal elsewhere in Europe. This is consistent with observed patterns of climate change across the continent. Additionally, we found that fire danger indices and area burned were cross-correlated in Greece, Spain and Finland, although the correlations were not very high. Moreover, fires were only related to currentyear climate variables. Though the meteorological conditions influencing on fire danger have changed in some areas, forest fires have not necessarily followed suit. For example, in the Mediterranean region, burned area has decreased, though FWI values show an increasing trend. This is consistent with the fact that weather and climate are major factors controlling fires, but not the only ones. The prediction of the occurrence of fires during the coming decades requires, in addition to climate research, comprehensive knowledge of socioeconomic aspects influencing fires and fire suppression. Furthermore, the foreseen ecological changes, like the changes in forest structures and dominant tree species, must be taken into account when the future fire conditions are estimated. The versatility of this problem emphasizes the importance of cross-disciplinary forest fire research.

The Supplement related to this article is available online at doi:10.5194/nhess-14-1477-2014-supplement.

Acknowledgements. The research leading to these results has received funding from the European Union's Seventh Framework Programme (FP7/2007-2013) under grant agreement no. 243888 (FUME project). The authors also wish to express their cordial thanks to Ewan O'Connor for linguistic revision. ECMWF ERA-40 and ERA Interim data used in this study have been obtained from the ECMWF data server.

Edited by: P. Tarolli

Reviewed by: four anonymous referees

\section{References}

Acero, F., García, J., Gallego, M., Parey, S., and Dacunha-Castelle, D.: Trends in Summer Extreme Temperatures over the Iberian Peninsula using Non-Urban Station Data, J. Geophys. Res. Atmos., 119, 39-53, doi:10.1002/2013JD020590, 2014.

Andrews, P., Loftsgaarden, D., and Bradshaw, L.: Evaluation of fire danger indexes using logistic regression and percentile analysis, Int. J. Wildlad Fire, 12, 213-226, 2003.

Bajocco, S. and Ricotta, C.: Evidence of selective burning in Sardinia (Italy): which land-cover classes do wildfires prefer?, Landscape Ecol., 23, 241-248, doi:10.1007/s10980-007-9176-5, 2008.

Bedia, J., Herrera, S., Gutiérrez, J. M., Zavala, G., Urbieta, I. R., and Moreno, J. M.: Sensitivity of fire weather index to different reanalysis products in the Iberian Peninsula, Nat. Hazards Earth Syst. Sci., 12, 699-708, doi:10.5194/nhess-12-699-2012, 2012.

Bedia, J., Herrera, S., Martín, D. S., Koutsias, N., and Gutiérrez, J. M.: Robust projections of Fire Weather Index in the Mediterranean using statistical downscaling, Climatic Change, 120, 229 247, 10.1007/s10584-013-0787-3, 2013.

Beguería, S., Angulo-Martínez, M., Vicente-Serrano, S., LópezMoreno, J., and El-Kenawy, A.: Assessing trends in extreme precipitation events intensity and magnitude using non-stationary peaks-over-threshold analysis: a case study in northeast Spain from 1930 to 2006, Int. J. Climatol., 31, 2102-2114, 2011.

Bessie, W. C. and Johnson, E. A.: The relative importance of fuels and weather on fire behavior in sub-Alpine forests, Ecology, 76, 747-762, doi:10.2307/1939341, 1995.

Beverly, J. L. and Martell, D. L.: Characterizing extreme fire and weather events in the Boreal Shield ecozone of Ontario, Agr. Forest Meteorol., 133, 5-16, doi:10.1016/j.agrformet.2005.07.015, 2005.

Bowman, D., Balch, K., Artaxo, P., Bond, W., Carlson, J., Cochrane, M., D’Antonio, C., DeFries, R., Doyle, J., Harrison, S., Johnston F., Keeley, J., Krawchuk, M., Kull, C., Marston, J., Moritz, M., Prentice, C., Roos, C., Scott, A., Swetnam, T., Der Werf, G., and Pyne, S.: Fire in the Earth System. Science, 324, 481-484, 2009.

Bradstock, R. A.: A biogeographic model of fire regimes in Australia: current and future implications, Global Ecol. Biogeogr., 19, 145-158, doi:10.1111/j.1466-8238.2009.00512.x, 2010.

Brotons, L., Aquilué, N., de Cáceres, M., Fortin, M., and Fall, A.: How Fire History, Fire Suppression Practices and Climate Change Affect Wildfire Regimes in Mediterranean Landscapes, PLoS ONE 8, e62392, 2013.

Brunet, M., Jones, P., Sigró, J., Saladié, O., Aguilar, E., Moberg, A., Della-Marta, P., Lister, D., Walther, A., and López, D.: Temporal and spatial temperature variability and change over Spain during 1850-2005, J. Geophys. Res. Atmos., 112, D12117, doi:10.1029/2006JD008249, 2007.

Camia, A. and Amatulli, G.: Weather factors and fire danger in the Mediterranean, in: Earth Observation of Wildland Fires in Mediterranean Ecosystems, edited by: Chuvieco, E., Springer Berlin Heidelberg, 71-82, 2009.

Camia, A., Amatulli, G., and San-Miguel-Ayanz, J. Past and future trends in forest fire danger in Europe, JRC Scientific and Technical Reports, EUR 23427 EN, 7 pp., Ispra, Italy, 2008.

Camia, A., Durrant Houston, T., and San-Miguel, J.: The European Fire Database: Development, Structure and Implementation, in: Proc. VI International Conference on Forest Fire Research, edited by: Viegas, D. X., Coimbra, 2010.

Carmo, M., Moreira, F., Casimiro, P., and Vaz, P.: Land use and topography influences on wildfire occurrence in northern Portugal, Landscape Urban Plan., 100, 169-176, doi:10.1016/j.landurbplan.2010.11.017, 2011.

Carvalho, A., Flannigan, M. D., Logan, K., Miranda, A. I., and Borrego, C.: Fire activity in Portugal and its relationship to weather and the Canadian Fire Weather Index System, Int. J. Wildland Fire, 17, 328-338, doi:10.1071/Wf07014, 2008.

Dee, D., Uppala, S., Simmons, A., Berrisford, P., Poli, P. Kobayashi, S., Andrae, U., Balmaseda, M., Balsamo, G., Bauer, P., Bechtold, P., Beljaars, A., van de Berg, L., Bidlot, J., Bormann, N., Delsol, C., Dragani, R., Fuentes, M., Geer, A., Haimberger, L., Healy, S., Hersbach, H., Hólm, E., Isaksen, L., Kåll- 
berg, P., Köhler, M., Matricardi, M., McNally, A., Monge-Sanz, B. M., Morcrette, J., Park, B., Peubey, C., de Rosnay, P., Tavolato, C., Thépaut, J.-N., and Vitart, F.: The ERA-Interim reanalysis: configuration and performance of the data assimilation system, Q. J. R. Meteorol. Soc., 137, 553-597, 2011.

De Groot, W., Goldammer. J., Keenan, T., Brady, M., Lynham., T., Justice, C., Csiszar, I., and O'Loughlin, K.: Developing a global early warning system for wildland fire, in: Proceedings of V International Conference on Forest Fire Research, edited by: Viega, D., 2006.

Della-Marta, P., Luterbacher, J., von Weissenfluh, E., Xoplaki, E., Brunet, M., and Wanner, H.: Summer heat waves over western Europe 1880-2003, their relationship to large-scale forcings and predictability, Clim. Dynam., 29, 251-275, doi:10.1007/s00382007-0233-1, 2007.

Dimitrakopoulos, A., Gogi, C., Stamatelos, G., and Mitsopoulos, I.: Statistical analysis of the fire environment of large forest fires (> 1000 ha) in Greece, Polish J. Environ. Studies, 20, 327-332, 2011a.

Dimitrakopoulos, A. P., Bemmerzouk, A. M., and Mitsopoulos, I. D.: Evaluation of the Canadian fire weather index system in an eastern Mediterranean environment, Meteorol. Appl., 18, 83-93, doi:10.1002/met.214, 2011b.

Dimitrakopoulos, A. P., Vlahou, M., Anagnostopoulou, C. G., and Mitsopoulos, I. D.: Impact of drought on wildland fires in Greece: implications of climatic change?, Climatic Change, 109, 331-347, doi:10.1007/s10584-011-0026-8, 2011c.

Drobyshev, I., Niklasson, M., and Linderholm, H. W.: Forest fire activity in Sweden: Climatic controls and geographical patterns in 20th century, Agr. Forest Meteorol., 154-155, 174-186, doi:10.1016/j.agrformet.2011.11.002, 2012.

EEA: Climate change, impacts and vulnerability in Europe, An indicator-based report. EEA report 12/2012, Luxembourg: Office for Official Publications of the European Union, 2012 ISBN 978-92-9213-346-7, ISSN 1725-9177 doi:10.2800/66071, 2012.

Feidas, H., Noulopoulou, C., Makrogiannis, T., and Bora-Senta, E.: Trend analysis of precipitation time series in Greece and their relationship with circulation using surface and satellite data: 19552001, Theor. Appl. Climatol., 87, 155-177, 2007.

Fernández-Montes, S., Rodrigo, F., Seubert, S., and Sousa, P.: Spring and summer extreme temperatures in Iberia during last century in relation to circulation types, Atmos. Res., 127, 154$177,2013$.

Finnish Forest Research Institute: Finnish Statistical Yearbook of Forestry. Finnish Forest Research Institute, 472 pp., Helsinki, Finland, 2010 (in Finnish with summary and captions in English).

Fujioka, F., Gill, A., Viegas, D., and Wotton, B.: Fire Danger and Fire Behavior Modeling Systems in Australia, Europe, and North America, in: Developments in Environmental Sciences, edited by: Bytnerowicz, A., Arbaugh, M. J., Riebau, A. R., and Andersen, C., 471-497, Elsevier, Netherlands and United Kingdom, 2008.

Ganteaume, A. and Jappiot, M.: What causes large fires in Southern France, Forest Ecol. Manage., 294, 76-85, doi:10.1016/j.foreco.2012.06.055, 2013.

Ganteaume, A., Camia, A., Jappiot, M., San-Miguel-Ayanz, J., Long-Fournel, M., and Lampin, C.: A review of the main driving facors of forest fire ignition over Europe, Environ. Manage., 51, 651-662, 2013.

Gillet, N., Weaver, A., Zwiers, F., and Flannigan, M.: Detecting the effect of climate change on Canadian forest fires, Geophys. Res. Lett., 31, L18211, doi:10.1029/2004GL020876, 2004.

Hamed, K. H. and Rao, A. R.: A modified Mann Kendall trend test for autocorrelated data, J. Hydrol., 204, 182-196, 1998.

Haylock, M., Hofstra, N., Klein Tank, A., Klok, E., Jones, P., and New, M.: A European daily high-resolution gridded data set of surface temperature and precipitation for 1950-2006, J. Geophys. Res., 113, D20119, doi:10.1029/2008JD010201, 2008.

Holden, Z. A., Morgan, P., Crimmins, M. A., Steinhorst, R. K., and Smith, A. M. S.: Fire season precipitation variability influences fire extent and severity in a large southwestern wilderness area, United States, Geophys. Res. Lett., 34, 1-5, doi:10.1029/2007g1030804, 2007.

IPCC: Summary for Policymakers, in: Climate Change 2013: The Physical Science Basis. Contribution of Working Group I to the Fifth Assessment Report of the Intergovernmental Panel on Climate Change, edited by: Stocker, T. F., Qin, D., Plattner, G.-K., Tignor, M., Allen, S. K., Boschung, J., Nauels, A., Xia, Y., Bex, V., and Midgley, P. M., Cambridge University Press, Cambridge, United Kingdom and New York, NY, USA, 2013.

Kailidis, D. and Karanikola, P.: Forest fires 1990-2000, GiachoudiGiapouli, Thessaloniki, 2004.

Kalimeris, A., Founda, D., Giannakopoulos, C., and Pierros, F.: Long-term precipitation variability in the Ionian Islands, Greece (Central Mediterranean): climatic signal analysis and future projections, Theor. Appl. Climatol., 109, 51-72, doi:10.1007/s00704-011-0550-5, 2012.

Karali, A., Hatzaki, M., Giannakopoulos, C., Roussos, A., Xanthopoulos, G., and Tenentes, V.: Sensitivity and evaluation of current fire risk and future projections due to climate change: the case study of Greece, Nat. Hazards Earth Syst. Sci., 14, 143-153, doi:10.5194/nhess-14-143-2014, 2014.

Kendall, M. G.: Rank correlation methods, Griffin, London, 1975.

Kistler, R., Kalnay, E., Collins,W., Saha, S., White, G., Woollen, J., Chelliah, M., Ebisuzaki,W., Kanamitsu, M., Kousky, V., van den Dool, H., Jenne, R., and Fiorino, M.: The NCEP-NCAR 50year reanalysis: Monthly means CD-ROM and documentation, B. Amer. Meteorol. Soc., 82, 247-268, 2001.

Kolokythas, K. V. and Argiriou, A. A.: Homogenization of Temperature Time Series of Western Greece, in: Advances in Meteorology, Climatology and Atmospheric Physics, edited by: Helmis, C. G. and Nastos, P. T., Springer Atmospheric Sciences, Springer Berlin Heidelberg, 535-540, 2013.

Koutsias, N., Martinez-Fernandez, J., and Allgower, B.: Do factors causing wildfires vary in space? Evidence from geographically weighted regression, GISci. Remote Sens., 47, 221-240, doi:10.2747/1548-1603.47.2.221, 2010.

Koutsias, N., Arianoutsou, M., Kallimanis, A. S., Mallinis, G., Halley, J. M., and Dimopoulos, P.: Where did the fires burn in Peloponnisos, Greece the summer of 2007? Evidence for a synergy of fuel and weather, Agr. Forest Meteorol., 156, 41-53, 2012.

Koutsias, N., Xanthopoulos, G., Founda, D., Xystrakis, F., Nioti, F., Pleniou, M., Mallinis, G., and Arianoutsou, A.: On the relationship between forest fires and weather conditions in Greece from long-term national observations (1894-2010), Int. J. Wildland Fire, 22, 493-507, 2013. 
Lehtonen, I., Ruosteenoja, K., Venäläinen, A., and Gregow, H.: The projected 21st century forest fire risk in Finland under different greenhouse gas scenarios, Boreal Environ. Res., 19, 127-139, 2014.

Lloyd-Hughes, B. and Saunders, M. A.: A drought climatology for Europe, Int. J. Climatol., 22, 1571-1592, doi:10.1002/joc.846, 2002.

Maheras, P., Patrikas, I., Karacostas, T., and Anagnostopoulou, C.: Automatic classification of circulation types in Greece: methodology, description, frequency, variability and trend analysis, Theor. Appl. Climatol., 67, 205-223, doi:10.1007/s007040070010, 2000.

Mäkelä, H. M., Laapas, M., and Venäläinen, A.: Long-term temporal changes in the occurrence of a high forest fire danger in Finland, Nat. Hazards Earth Syst. Sci., 12, 2591-2601, doi:10.5194/nhess-12-2591-2012, 2012.

Mann, H. B.: Nonparametric tests against trend, Econometrica, Econometrica, 13, 245-259, 1945.

Martínez-Fernández, J., Chuvieco, E., and Koutsias, N.: Modelling long-term fire occurrence factors in Spain by accounting for local variations with geographically weighted regression, Nat. Hazards Earth Syst. Sci., 13, 311-327, doi:10.5194/nhess-13-311-2013, 2013.

Meyn, A., Schmidtlein, S., Taylor, S. W., Girardin, M. P., Thonicke, K., and Cramer, W.: Spatial variation of trends in wildfire and summer drought in British Columbia, Canada, 1920-2000, Int. J. Wildland Fire, 19, 272-283, 2010.

Moberg, A. and Jones, P. D.: Trends in indices for extremes in daily temperature and precipitation in central and western Europe, 1901-99, Int. J. Climatol., 25, 1149-1171, doi:10.1002/joc.1163, 2005.

Moreira, F., Viedma, O., Arianoutsou, M., Curt, T., Koutsias, N., Rigolot, E., Barbati, A., Corona, P., Vaz, P., Xanthopoulos, G., Mouillot, F., and Bilgili, E.: Landscape - wildfire interactions in southern Europe: Implications for landscape management, J. Environ. Manage., 92, 2389-2402, doi:10.1016/j.jenvman.2011.06.028, 2011.

Moreno, M., Malamud, B., and Chuvieco, E.: Wildfire frequencyarea statistics in Spain, Proc. Environ. Sci., 7, 182-187, $2011 \mathrm{a}$.

Moreno, J. M., Viedma, O., Zavala, G., and Luna, B.: Landscape variables influencing forest fires in central Spain, Int. J. Wildland Fire, 20, 678-689, 2011b.

Moriondo, M., Good, P., Durao, R., Bindi, M., Giannakopoulos, C., and Corte-Real, J.: Potential impact of climate change on fire danger in the Mediterranean area, Clim. Res., 31, 85-95, 2006.

Moritz, M. A., Moody, T. J., Krawchuk, M. A., Hughes, M., and Hall, A.: Spatial variation in extreme winds predicts large wildfire locations in chaparral ecosystems, Geophys. Res. Lett., 37, L04801, doi:10.1029/2009g1041735, 2010.

Nastos, P. T., Philandras, C. M., Founda, D., and Zerefos, C. S.: Air temperature trends related to changes in atmospheric circulation in the wider area of Greece, Int. J. Remote Sens., 32, 737-750, doi:10.1080/01431161.2010.517796, 2011.

Pausas, J. G.: Changes in fire and climate in the eastern Iberian Peninsula (Mediterranean Basin), Climatic Change, 63, 337350, 2004

Pereira, M. G., Malamud, B. D., Trigo, R. M., and Alves, P. I.: The history and characteristics of the 1980-2005 Portuguese ru- ral fire database, Nat. Hazards Earth Syst. Sci., 11, 3343-3358, doi:10.5194/nhess-11-3343-2011, 2011.

Pérez, F. and Boscolo, R.: Clima en España: Pasado, Presente y Futuro. Informe de evaluación del cambio climático regional, Clivar España, available at: www.clivar.es/files/informe_clivar_ final.pdf (last access: 6 June 2014), 2010.

Piñol, J., Terradas, J., and Lloret, F.: Climate warming, wildfire hazard, and wildfire occurrence in coastal eastern Spain, Climatic Change, 38, 345-357, 1998.

Pnevmatikos, J. D. and Katsoulis, B. D.: The changing rainfall regime in Greece and its impact on climatological means, Meteorol. Appl., 13, 331-345, doi:10.1017/S1350482706002350, 2006.

Sen, P.: Estimates of the regression coefficient based on Kendall's tau, J. Am. Stat. Assoc., 63, 1379-1389, 1968.

Sullivan, A. L.: Wildland surface fire spread modelling, 1990-2007, 2: Empirical and quasi-empirical models, Int. J. Wildland Fire, 18, 369-386, 2009.

Tanskanen, H., Venäläinen, A., Puttonen, P., and Granström, A.: Impact of stand structure on surface fire ignition potential in Picea abies and Pinus sylvestris forests in southern Finland, Can. J. For. Res,. 35, 410-420, 2005.

Tietäväinen, H., Tuomenvirta, H., and Venäläinen, A.: Annual and seasonal mean temperatures in Finland during the last 160 years based on gridded temperature data, Int. J. Climatol., 30, 2247 2256, 2010.

Uppala, S., Kallberg, P., Simmons, A., Andrae, U., Bechtold, V., Fiorino, M., Gibson, J., Haseler, J., Hernandez, A., Kelly, G., Li, X., Onogi, K., Saarinen, S., Sokka, N., Allan, R., Andersson, E., Arpe, K., Balmaseda, M., Beljaars, A., Van De Berg, L., Bidlot, J., Bormann, N., Caires, S., Chevallier, F., Dethof, A., Dragosavac, M., Fisher, M., Fuentes, M., Hagemann, S., Holm, E., Hoskins, B., Isaksen, L., Janssen, P., Jenne, R., McNally, A., Mahfouf, J., Morcrette, J., Rayner, N., Saunders, R., Simon, P., Sterl, A., Trenberth, K., Untch, A., Vasiljevic, D., Viterbo, P., and Woollen, J.: The ERA-40 re-analysis, Q. J. R. Meteorol. Soc., 131, 2961-3012, 2005.

Van Wagner, C.: Development and structure of the Canadian Forest Fire Weather IndexSystem. Canadian Forestry Service, Ottawa, Ontario, Forestry Technical Report, 35, 37 pp., 1987.

Vázquez, A. and Moreno, J. M.: Sensitivity of fire occurrence to meteorological variables in Mediterranean and Atlantic areas of Spain, Landscape Urban Plan., 24, 129-142, doi:10.1016/01692046(93)90091-Q, 1993.

Vázquez, A. and Moreno, J. M.: Patterns of fire occurrence across a climatic gradient and its relationship to meteorological variables in Spain, in: Global Change and Mediterranean-Type 10 Ecosystems, edited by: Moreno, J. M. and Oechel, W. C., Ecological Studies 117, Springer-Verlag, New York, 408-434, 1995.

Viedma, O., Moreno, J. M., and Rieiro, I.: Interactions between land use/land cover change, forest fires and landscape structure in Sierra de Gredos (Central Spain), Environ. Conservation, 33, 212-222, 2006.

Viedma, O., Angeler, D. G., and Moreno, J. M.: Landscape structural features control fire size in a Mediterranean forested area of central Spain, Int. J. Wildland Fire, 18, 575-583, doi:10.1071/Wf08030, 2009.

Wastl, C., Schunk, C., Leuchner, M., Pezzatti, G., and Menzel, A. Recent climate change: Long-term trends in meteorological for- 
est fire danger in the Alps, Agr. Forest Meteorol., 162-163, 1-13, 2012.

Xystrakis, F. and Koutsias, N.: Differences of fire activity and their underlying factors among vegetation formations in Greece, iForest - Biogeosci. Forest., 6, 132-140, doi:10.3832/ifor0837-006, 2013.

Xystrakis, F., Kallimanis, A. S., Dimopoulos, P., Halley, J. M., and Koutsias, N.: Precipitation dominates fire occurrence in Greece (1900-2010): its dual role in fuel build-up and dryness, Nat. Hazards Earth Syst. Sci., 14, 21-32, doi:10.5194/nhess-14-21-2014, 2014.
Zeileis, A., Leisch, F., Hornik, K., and Kleiber, C.: strucchange: An $\mathrm{R}$ Package for Testing for Structural Change in Linear Regression Models, J. Stat. Softw., 7, 1-38, 2002.

Zeileis, A., Kleiber, C., Krämer, W., and Hornik, K.: Testing and dating of structural changes in practice, Comput. Statistics Data Analysis, 44, 109-123, 2003. 